\title{
ANALISIS BUTIR SOAL ULANGAN AKHIR MATA PELAJARAN KIMIA KELAS XI SEMESTER GANJIL TAHUN AJARAN 2019/2020 SMA NEGERI 2 TOMIA
}

\author{
Nurpila1)*, La Rudi 1), Rustam Musta ${ }^{1)}$ \\ ${ }^{1}$ Pendidikan Kimia FKIP Universitas Halu Oleo, Kendari \\ Corresponding author: larudi.fkip@uho.ac.id
}

\begin{abstract}
Abstrak
Penelitian ini bertujuan untuk mengetahui kualitas butir soal dan indikator serta distribusi jenjang ranah kognitif Taksonomi Bloom mata pelajaran kimia kelas XI semester ganjil Tahun Ajaran 2019/2020 di SMA Negeri 2 Tomia. Objek dalam penelitian ini mencakup seluruh butir soal dan lembar jawaban siswa kelas XI di SMA Negeri 2 Tomia. Data dikumpulkan dengan teknik dokumentasi. Data penelitian yang dianalisis yaitu semua lembar jawaban siswa yang mengikuti ulangan semester ganjil mata pelajaran Kimia. Berdasarkan hasil analisis data diperoleh bahwa soal ulangan akhir semseter (UAS) mata pelajaran kimia kelas XI semester ganjil di SMA Negeri 2 Tomia seluruhnya memiliki butir soal yang valid; dengan derajat keterandalan yang tinggi dengan koefisien reliabilitas $r_{11}=$ 0,73 . Tingkat kesukaran soal mata pelajaran kimia kelas XI terdapat 1 butir soal yang tergolong sangat mudah (25\%), 2 butir soal tergolong mudah (75\%) dan 4 butir soal yang tergolong sedang. Daya pembeda soal soal UAS mata pelajaran kimia kelas XI terdapat 1 soal yang tergolong baik, 4 nomor tegolong cukup dan 2 nomor tergolong buruk. Butir soal UAS mata pelajaran kimia untuk kelas XI seluruhnya sesuai dengan indikator pembelajaran. Distribusi jenjang ranah kognitif butir soal terdapat 1 butir soal termasuk dalam ranah kognit C2(memahami), terdapar 3 butir soal yang termasuk dalam ranah kognitif C3 (mengaplikasikan) serta 3 soal dalam ranah kognitif C4 (menganalisis).
\end{abstract}

Kata Kunci: Analisis Butir Soal, Validitas, Reliabilitas, Tingkat Kesukaran, Daya pembeda, Ranah Kognitif soal kimia

\section{PENDAHULUAN}

Dalam

melakasanakan

evaluasi pembelajaran seorang guru harus nemiliki komptensi guru. Kompetensi guru merupakan seperangkat pengetahuan, keterampilan, dan prilaku yang harus dimiliki, dihayati, dikuasai, dan diaktualisasi oleh guru dalam melaksanakan tugas keprofesionalan. Kompetensi guru terbagi menjadi empat kompetensi yaitu, kompetensi pedagogik, kompetensi profesional, kompetensi individu, serta kompetensi sosial. Masingmasing kompetensi memiliki beberapa kompetensi inti yang harus dikuasai oleh guru. Salah satu kompetensi inti pada kompetensi pedagogik adalah menyelenggarakan penilaian dan evaluasi proses dan hasil belajar (Prabayanti dkk, 2018). 
Selain itu dalam pelaksanaan evaluasi pembelajaran pemerintah juga telah mengeluarkan beberapa peraturan tentang kompetensi yang harus dimiliki oleh seorang guru dalam melaksanakan kegiatan evaluasi pembelajaran. Menurut peraturan Menteri Pendidikan Nasional Republik Indonesia Nomor 16 Tahun 2007 tentang standar kualifikasi akademik dan kompetensi guru. Kompetensi yang harus dimiliki dalam menyelenggarakan penilaian dan evaluasi proses dan hasil belajar yait memahami prinsip-prinsip penilaian dan evaluasi proses dan hasil belajar sesuai dengan karakteristik mata pelajaran yang diampuh, menentukan aspek-aspek proses dan hasil belajar yang penting untuk dinilai dan dievaluasi sesuai dengan karakteristik mata pelajaran yang diampuh, menentukan prosedur penilaian dan evaluasi proses dan hasil belajar, mengembangkan instrumen penilaian dan evaluasi proses dan hasil belajar, mengadministrasikan penilaian proses dan hasil belajar secara berkesinambungan dengan mengunakan berbagai instrument menganalisis hasil penilaian proses dan hasil belajar untuk berbagai tujuan, dan melakukan evaluasi proses dan hasil belajar.

Alat evaluasi atau tes yang digunakan haruslah memiliki kualitas yang baik. Tes yang baik harus dapat dipertanggung jawabakan dalam segi kelayakan, kesahihan keterpercayaan (validitas), (reliabilitas), ketafsiran, kebergunaan, dan efektivitas butir soal yang meliputi tingkat kesulitan dan daya pembeda soal yang baik. jika tes yang digunakan mutunya tidak baik, maka akan mengakibatkan kesalahan pengukuran kemampuan siswa. Kualitas suatu tes hasil belajar sangat ditentukan oleh kualitas itemitemnya (Febriani, 2016).

Tes hasil belajar yang berisi item-item yang berkualitas tinggi walaupun dalam jumlah yang sedikit akan jauh lebih berguna dari pada tes hasil belajar yang berisi puluhan item berkualitas rendah yang akan menurunkan fungsi tes dan hasil pengukuran yang menyesatkan Untuk mengetahui kualitas soal dapat diungkap melalui analisis butir soal. Analisis butir soal dapat dilakukan secara efektif dan efisien melalui bantuan aplikasi dalam jumlah yang sedikit akan jauh lebih berguna dari pada tes hasil belajar yang berisi puluhan item berkualitas rendah yang akan menurunkan fungsi tes dan hasil pengukuran yang menyesatkan (Khaerudin, 2015).

Menurut Purwanto (2008) salah satu jenis soal tes yang perlu dianalisis adalah soal tes semester. Soal tes semester bertujuan mengukur hasil belajar siswa dan hasil penilaian tes semester berguna untuk menentukan prestasi setiap siswa 
dibandingkan dengan siswa yang lain dalam kelasnya. Soal Ulangan Akhir Semester (UAS) merupakan alat evaluasi pendidikan yang digunakan guru untuk mengetahui tingkat pencapaian kompetensi siswa di akhir pembelajaran (Yustika dkk, 2014). Soal UAS perlu dianalisis untuk untuk mengetahui kualitas dari tes atau soal tersebut. Untuk mengetahui kualitas suatu soal atau tes dapat diungkap melalui analisis butir soal.

Analisis butir soal merupakan salah satu jenis kegiatan guru yang sangat bermanfaat dalam menafsirkan hasil belajar peserta didik dan untuk mengetahui kualitas soal (Nur dkk, 2018). Analisis butir soal dapat memberikan informasi secara terinci tentang keadaan masingmasing butir soal seperti kekuatan dan kelemahan butir soal, spesifikasi soal secara lengkap dan masalah yang terkandung dalam soal seperti kesalahan dalam pembuatan kunci jawaban, soal terlalu sukar atau mudah dan lain sebagainya. Analisis butir soal dapat dilakukan secara efektif dan efisien melalui bantuan aplikasi komputer (Suaedi, 2016).

Setelah melakukan observasi di SMA Negeri 2 Tomia diperoleh data bahwa, pada hasil ulangan akhir semester siswa kelas XI mata pelajaran kimia semester ganjil tahun ajaran 2019/2020 di
SMA Negeri 2 Tomia khususnya kelas XI MIPA masih terdapat siswa yang memperoleh nilai jauh dibawah nilai KKM. Dari 90 siswa yang mengikuti ulangan akhir semester mata pelajaran kimia terdapat 13 orang siswa yang memperoleh nilai dibawah nilai 60 , bahkan diantaranya ada yang memperoleh nilai 15 dan 30 dari nilai 100. Jika dipersentasekan siswa yang berhasil memproleh nilai $\geq 60$ sebanyak $85,5 \%$ dan yang memperoleh nilai dibawah 60 sebanyak 14,5\%. Berdasarkan informasi yang diperoleh dari lokasi penelitian khususnya melalui konsultasi dengan guru bidang studi kimia. Guru yang bersangkutan ingin meningkatkan taraf kecapaian nilai KKM pada mata pelajaran kimia yang semula $85 \%$ ditingkatkan menjadi $90 \%$. Hal ini dilakukan dengan tujuan untuk meningkatkan hasil belajar siswa dan membantu siswa mencapai ketuntasan nilai KKM pada mata pelajaran kimia ditahun ajaran selanjutnya.

Hasi belajar yang dinyatakan sebagai tujuan pembelajaran akan menentukan banyak hal dalam proses mempedomani hasil belajar umum (kompetensi inti dan kompetensi dasar) yang telah dikembangkan dan ditetapkan dalam kurikulum resmi. Demikian juga dalam mengembangkan instrumen pengukuran yang akan digunakan untuk mengukur 
pencapaian murid dalam tujuan pembelajaran tersebut, dan dalam merencanakan kegiatan-kegiatan pembelajaran yang dimaksudkan untuk membantu murid-murid mencapai ketuntasan dalam pengetahuan keterampilan dan sikap yang nanti akan diukur pencapaiannya (Popham dkk, 2002).

Salah satu faktor yang mempengaruhi hasil belajar siswa adalah kualitas tes. Menurut Arikunto (2013) tes merupakan alat untuk mengukur dan menegetahui hasil bealajar siswa dengan cara-cara yang sudah ditentukan. Maka dalam pembuatan tes sebaikanya memperhatikan aturan aturan tertentu agar tes dapat berfungsi secara maksimal bagi siswa yang mengerjakan serta dapa mengukur dengan baik kemampuan siswa dalam suatu pembelajaran.

Berdasarkan informasi awal yang diperoleh dari lokasi penelitian khususnya melalui konsultasi dengan guru mata pelajaran kimia kelas XI SMAN 2 Tomia soal ujian akhir semester ganjil mata pelajaran kimia kelas XI SMA Negeri 2 Tomia tahun pelajaran 2019/2020 yang dilaksanakan di SMA Negeri 2 Tomia berupa uraian yang disusun sendiri oleh guru pengampuh bidang studi kimia di sekolah tersebut. Kemudian soalsoal yang digunakan untuk tes semester ganjil tahun pelajaran 2019/2020 tersebut belum pernah diuji coba atau dianalisis baik secara kualitatif maupun kuantitatif, baik dari tingkat kesukaran soal, daya pembeda soal, distraktor, validitas butir soal maupun reliabilitasnya. Sehingga butir-butir soal yang diujikan tersebut belum diketahui apakah soal-soal tersebut sudah memiliki kualitas yang baik atau belum. Untuk mengetahui kualitas soal yang dibuat oleh guru tersebut perlu dilakukan analisis butir soal tes hasil belajar siswa baik secara kualitatif dan kuantitatif untuk mengetahui apakah soal tes hasil belajar siswa di SMA Negeri 2 Tomia kelas XI semester ganjil tahun pelajaran 2019/2020 telah dapat dikategorikan sebagai soal yang memiliki kualitas yang baik atau tidak. Sehingga dapat diketahui butir-butir soal yang perlu diperbaiki ataupun diganti serta yang dapat digunakan kembali sebagai tes hasil belajar pada tahun berikutnya.

\section{METODE PENELITIAN}

Penelitian telah dilaksanakan pada bulan September-Oktober di Fakultas Keguruan dan IImu Pendidikan Universitas Haluoleo, Kendari. Pengambilan data dilakukan pada minggu pertama bulan September tahun 2020 di SMA Negeri 2 Tomia. Rancangan 
penelitian berupa penelitian deskriptif yang bersifat ex post facto. Objek penelitian adalah silabus, kisi-kisi soal, lembar soal dan lembar jawaban siswa pada ujian semester ganjil mata pelajaran kimia kelas XI MIPA SMA Negeri 2 Tomia tahun ajaran 2019/2020.

Analisis soal ujian semester ganjil mata pelajaran kimia kelas XI MIPA SMA Negeri 2 Tomia dilakukan secara kualitatif dan kuantitatif. Analisis kuantitatif butir soal dilakukan secara statistik yaitu analisis validitas butir, reliabilitas, soal tingkat kesukaran, daya pembeda, dan kesalahan baku pengukuran soal.. Analisis secara kualitatif dilihat dari kesesuaian butir soal dan indikator serta distribusi ranah kognitif taksonomi Bloom.

\section{Teknik Pengumpulan Data}

Data dikumpulkan dengan teknik dokumentasi. Data penelitian yang dianalisis yaitu semua lembar jawaban siswa kelas XI MIPA 1, 2 dan 3 yang mengikuti ulangan semester ganjil mata pelajaran Kimia di SMA Negeri 2 Tomia Tahun Ajaran 2019/2020.

\section{Teknik Analisis Data}

Setelah data diperoleh, maka dilakukan analisis kualitatif dan kuantitatif. Analisis kuantitatif dilakukan dengan cara menyesuaikan soal dengan indikator dan dengan melihat distribusi jenjang ranah kognitif taksonomi Bloom. Analisis kuantitatif butir soal dilakukan secara statistik yaitu; validitas item soal, reliabilitas, tingkat kesukaran, daya pembeda dan Kesalahan Baku Pengukuran (KBP).

\section{HASIL DAN PEMBAHASAN}

\section{Validitas Item Soal}

Soal Ulangan Akhir Semster (UAS) mata pelajaran kimia pada semester ganjil tahun ajaran 2019/2020 yang diujikan pada kelas XI MIPA 1, 2 dan 3 SMAN 2 Tomia adalah soal yang sama. Jumlah siswa kelas XI MIPA yang mengikuti UAS berjumlah 90 orang. Terdiri dari 29 orang siswa kelas MIPA 1, 31 orang siswa kelas MIPA 2 dan 30 orang siswa MIPA 3. Analisis dari segi validitas soal UAS mata pelajaran kimia kelas XI MIPA SMAN 2 Tomia dihitung dengan rumus korelasi Product Moment. Berikut ini adalah hasil perhitungan uji validitas soal UAS kelas XI MIPA menggunakan program Microsoft Excel diperoleh data bahwa keseluruhan butir soal UAS semester ganjil mata pelajaran kimia kelas XI MIPA tahun ajaran 2019/2020 dinyatakan valid karena masing-masing item memiliki nilai rhitumg lebih besar dari nilai rtabel pada taraf 
kepercayaan $95 \%\left(a_{0,05}\right)$. Dengan demikian, jika ditinjau dari validitas butir soalnya, maka tes hasil belajar mata pelajaran kimia kelas XI semester ganjil Tahun Ajaran 2019/2020 di SMA Negeri 2 Tomia termasuk instrumen tes yang baik dan mampu mengukur apa yang hendak diukur.

\section{Reliabilitas}

Hasil analisis data yang dilakukan diperoleh nilai r11 (koefisien reliabilitas) sebesar 0,73 . Hasil koefisien reliabilitas tes ujian semester ganjil pelajaran kimia kelas XI MIPA SMA Negeri Tomia tahun pelajaran 2019/2020 dapat dinyatakan sebagai tes yang reliabel karena nilai koefisien reliabilitasnya lebih besar dari 0,70 . Tes ini dikatakan reliabel artinya soal-soal tersebut memiliki keterandalan yang tinggi. Keterandalan yang dimaksud dalam hal ini meliputi ketepatan atau kecermatan hasil pengukuran atau kestabilan dari hasil pengukuran. Sehingga apabila dilakukan pengujian beberapa kali pada soal tes ini akan memberikan hasil yang tetap atau relatif sama (Chabib Thoha, 2003).

\section{Tingkat Kesukaran}

Dari hasil analisis penyebaran tingkat kesukaran butir soal UAS kimia semester tahun ajaran 2019/2020 menunjukkan dari 7 soal yang dianalisis terdapat 1 soal $(14,29 \%)$ berkategori sangat mudah, 2 butir soal $(28,57 \%)$ berkategori mudah, serta terdapat 4 butir soal $(57,14 \%)$ berkategori sedang.

Menurut Arikuntuo (2008) soal yang baik adalah soal yang tidak terlalu mudah dan tidak terlalu sulit atau sukar. Dengan kata lain bahwa soal yang dianggap baik yaitu soal-soal sedang yang mempunyai indeks kesukaran 0,3 sampai 0,7 .

Sebaran tingkat kesukaran soal UAS kelas XI MIPA yang diteliti termasuk kurang baik, karena tidak sesuai dengan petunjuk penulisan tes yang baik menurut Jayadi dalam Depdikbud (2005), yaitu dalam setiap perangkat soal tes harus memuat $30 \%$ soal mudah, $50 \%$ soal sedang dan $20 \%$ soal sukar, atau dengan perbandingan tingkat kesukaran soal untuk ketiga kategori mudah, sedang dan sukar adalah $3: 5: 2$, dengan kata lain apabila jumlah soal tes 7 butir maka sebaiknya terdiri dari 2 butir soal mudah, 4 butir soal sedang dan 1 butir soal sukar.

\section{Daya Pembeda}

Berdasarkan perhitungan analisis daya pembeda butir soal UAS kelas XI mata pelajaran kimia semester ganjil tahun ajaran 2019/2020 di SMA Negeri 2 Tomia terdapat 4 butir soal yang termasuk kategori 
soal yang cukup, yakni berada di antara $0,21<D B \leq 0,40$ Kemudian terdapat 2 soal soal yang termasuk kategori soal yang buruk, dan terdapat 1 butir soal yang termasuk kategori soal yang baik yakni berada di antara 0,41< DB $\leq 0,70$.

Charles

D. Hopkins dan

Richard

L. Antes

(1999)

mengatakan bahwa apabila suatu butir soal mempunyai daya pembeda yang baik maka dapat diartikan bahwa butir soal itu mampu membedakan antara peserta pelatihan yang berkemampuan tinggi dengan peserta pelatihan yang berkemampuan rendah. Soal yang mempunyai nilai $\mathrm{DB}=0,40$ dianggap sangat efektif dalam membedakan siswa yang berkemampuan tinggi dan berkemampuan rendah. Soal yang mempunyai nilai DB antara 0,20 0,39 dianggap memuaskan. Soal yang mempunyai nilai DB lebih rendah dari 0,20-0,39 harus diperbaiki.

Sejalan dengan Charles D. Hopkins dan Richard L. Antes (1999) soal yang berkategori baik dan cukup berarti soal tersebut dapat membedakan antara siswa kelompok pandai dan siswa kelompok kurang pandai dan soal yang berkategori buruk tidak dapat membedakan antara siswa kelompok pandai dan siswa kelompok kurang pandai. Soal yang berkategori baik dan cukup sebaiknya dimasukan kedalam bank soal sedangkan soal yang berkategori buruk sebaiknya tidak dipakai atau tidak dimasukan kedalam bank soal.

\section{Analisis Distribusi Jenjang} Ranah kognitif Taksonomi Bloom

Hasil analisis dari segi distribusi jenjang ranah kognitif soal UAS mata pelajaran kimia kelas XI MIPA SMAN 2 Tomia diperoleh bahwa hasil analisis distribusi jenjang ranah kognitif Taksonomi Bloom soal UAS mata pelajaran kimia kelas XI semester ganjil diperoleh, C2 (memahami) sebanyak 1 butir soal C3 (mengaplikasikan) sebanyak 3 butir soal serta C4 (menganalisis) sebanyak 3 butir soal.

Soal nomor 1 adalah soal yang tergolong pada jenjang ranah kognitif C2 (memahami). Menurut Anderson (2001) memahami diartikan sebagai kemampuan mengkonstruk makna atau pengertian berdasarkan pengetahuan awal yang dimiliki, mengaitkan informasi yang baru dengan pengetahuan yang telah dimiliki, atau mengintegrasikan pengetahuan yang baru ke dalam skema yang telah ada dalam pemikiran siswa. Karena penyususn skema adalah konsep, maka pengetahuan konseptual 
merupakan dasar pemahaman. Untuk soal nomor 1 termasuk dalam jenjang ranah kognitif $\mathrm{C} 2$ (memahami) pada kategori menafsirkan. Menafsirkan adalah kemampuan mengubah dari satu bentuk informasi ke bentuk informasi yang lainnya, misalnya dari kata-kata ke grafik atau gambar, atau sebaliknya, dari kata-kata ke angka, atau sebaliknya, maupun dari kata-kata ke kata-kata, misalnya meringkas atau membuat parafrase. Informasi yang disajikan dalam tes haruslah "baru" sehingga dengan mengingat saja siswa tidak akan bias menjawab soal yang diberikan.

Pada soal nomor 1 siswa diarahkan untuk memberikan nama dari struktur senyawa hidrokarbon khususnya pada senyawa alkena. Maka pada tahap ini siswa diarahkan untuk dapat mengetahui nama dari struktur tersebut. Jadi untuk mengetahui nama dari struktur senyawa tersebut siswa harus memahami tata cara penamaan senyawa alkena berdasarkan aturan IUPAC. Sehingga siswa bisa memberikan nama pada struktur alkana dengan benar.

Soal nomor 2 adalah soal yang tergolong pada jenjang ranah kognitif C3 (menerapkan). Menurut Anderson (2001) menerapkan diartikan sebagai kemampuan menerapkan informasi pada situasi nyata, dimana peserta didik mampu menerapkan pemahamannya dengan cara menggunakannya secara nyata. Di jenjang ini, peserta didik dituntut untuk dapat menerapkan konsep dan prinsip yang ia miliki pada situasi baru yang belum pernah diberikan sebelumnya.

Pada soal nomor 2, siswa diarahkan untuk membuat struktur senyawa hidrokarbon yaitu senyawa alkana. Maka pada tahap pertama siswa diarahkan untuk dapat untuk memahami dengan mendeskripsikani ciri-ciri dari 2,2,3,3-tetrametil butana. Misalnya, untuk metil memliki jumlah atom $C$ sebanyak 1 dan atom $\mathrm{H}$ sebanyak 3. Dan terdapat 4 subtituen metil pada senyawa tersebut, berarti terdapat terdapar 4 rangkap subtituen metil pada senyawa tersebut. Pada soal ini siswa diarahkan untuk membuat struktur dari 2,2,3,3-tetrametil butana. Setelah siswa bisa memahami kemudian siswa diarahkan untuk mebuat struktur dari 2,2,3,3-tetrametil butana. Pada tahap ini siswa hadapkan pada masalah yang baru. Maka untuk membuat struktur dari senyawa tersebut siswa harus menerapkan pemahamannya dalam membuat struktur dari 2,2,3,3-tetrametil butana.

Soal nomor 3 adalah soal tergolong pada jenjang ranah 
kognitif C3 (menerapkan) pada kategori menjalankan.

Menjalankan merupakan

kemampuan menjalankan suatu prosedur rutin yang telah dipelajari sebelumnya. Langkahlangkah yang diperlukan sudah tertentu dan juga dalam urutan tertentu. Apabila langkah-langkah tersebut benar, maka hasilnya sudah tertentu pula. Istilah lain untuk menjalankan adalah melakukan (carrying out).

Pada soal nomor 3, siswa diarahkan untuk menentukan $\Delta \mathrm{H}$ untuk pembentukan $\mathrm{mol} \mathrm{CH}_{4}$ dari pembakaran 4,8 gram $\mathrm{CH}_{4}$. Maka tahap awal yang dilakukan siswa adalah membuat reaksi pembakaran $\mathrm{CH}_{4}$. Pada tahap ini siswa diarahkan untuk bisa memahami bagaimana cara membuat reaksi pembakaran dari $\mathrm{CH}_{4}$. Setelah siwa memahami siswa diarahkan menggunakan pemahamannya dalam mebuat reaksi pembakaran $\mathrm{CH}_{4}$. Kemudian tahap kedua siswa diarahkan untuk menentukan jumlah mol pada $\mathrm{CH}_{4}$ dari pembakaran 4,8 gram $\mathrm{CH}_{4}$. Setelah siswa mengetahui jumlah mol dari $\mathrm{CH}_{4}$. Kemidian, siswa dirahkan untuk menetukan $\Delta \mathrm{H} \mathrm{CH} 4$. Maka pada tahap ini siswa dihadapkan pada masalah baru. Dari jumlah mol yang diperoleh siswa diarahkan untuk menentukan $\Delta \mathrm{H} \mathrm{CH}$. Jadi, untuk menyelesaikan masalah tersebut yakni menentukan $\Delta \mathrm{H}$
$\mathrm{CH}_{4}$ dari $\mathrm{mol} \mathrm{CH}_{4}$ yang diperoleh siswa diarahkan untuk menerapkan sebuah konsep yaitu Hukum Hess. Setelah siswa menerapkan konsep Hukum Hess, kemudian siswa diarahkan untuk bisa menjalankan rumus penentuan $\Delta \mathrm{H} \quad$ berdasarkan Hukum Hess. Apabila langkah langkah yang diambil sudah benar maka hasilnya akan benar pula.

Soal nomor 4 adalah soal tergolong pada jenjang ranah kognitif C3 (menerapkan) pada kategori menjalankan. Pada soal nomor 4, siswa diarahkan untuk menentukan $\Delta \mathrm{H} \mathrm{CH}$ berdasarkan beberapa data perubahan entalpi pembentukan standar. Maka tahap awal yang dilakukan siswa adalah membuat reaksi pembakaran $\mathrm{CH}_{4}$. Pada tahap ini siswa diarahkan untuk bisa memahami bagaimana cara membuat reaksi pembakaran dari $\mathrm{CH}_{4}$. Setelah siwa memahami kemudian siswa diarahkan menggunkan pemahamannya dalam membuat reaksi pembakaran $\mathrm{CH}_{4}$. Pada soal disajikan beberapa data perubahan entalpi. Setelah reaksi pembakaran dari $\mathrm{CH}_{4}$ dibuat. Selanjutnya, siswa diarahkan untuk menentukan $\Delta \mathrm{H} \quad \mathrm{CH}_{4}$ dari reaksi pembakar $\mathrm{CH}_{4}$ dan beberapa data perubahan entalpi. Maka pada tahap ini siswa dihadapkan pada masalah baru. Jadi, untuk menentukan $\Delta \mathrm{H} \mathrm{CH}_{4}$ siswa diarahkan untuk 
menggunakan rumus perubahan entalpi berdasarkan data perubahan entalpi. Kemudian tahap akhir siswa diarahkan untuk bisa menjalankan rumus penentuan $\Delta \mathrm{H} \quad$ berdasarkan beberapa data perubahan entalpi pembentukan. Apabila langkah langkah yang diambil sudah benar maka hasilnya akan benar pula.

Soal nomor 5 adalah soal tergolong pada jenjang ranah kognitif C4 (menganalisi). Menurut Anderson (2001) menganalsis diartikan sebagai kemampuan menguraikan informasi kedalam beberapa bagian menemukan asumsi, dan membedakan pendapat dan fakta serta menemukan hubungan sebab akibat.

$\begin{array}{llr}\text { Pada soal } & \text { nomor 5, } & \text { siswa } \\ \text { diarahkan } & \text { siswa } & \text { untuk } \\ \text { menentukan } & \text { persamaan } & \text { laju }\end{array}$
rekasi, orde rekasi, harga tetapan laju reaksi dan harga $V$. Pada point (a) siswa diminta untuk menetukan persamaan laju reaksi. Maka pada tahap ini siwa harus mengetahui dan memahami konsep dalam membuat persamaan laju reaksi. Sehingga bisa diterapkan dalam menetukan persamaan laju reaksi dari soal.. Kemudian pada point (b) siswa diminta untuk menentukan orde reaksi terhadap $\mathrm{Fe}^{3+}$ dan $\mathrm{S}^{2-}$. Pada tahap ini siswa diarahkan untuk menyeleksi data yang ada untuk diaplikasikan dalam menentukan nilai $\mathrm{m}$ dan $\mathrm{n}$. Hal ini dilakukan sebagai perwujudan dari level menganalisis. Pada point (c) siswa diminta untuk menentukan harga tetapan laju (k). Siswa dihadapkan pada masalah baru. Maka pada tahap ini siswa diarahkan untuk mengkorelasikan persamaan laju rekasi dengan nila $m$ dan $n$ yang telah didapat untuk menentukan harga tetapan laju reaksinya (k). Kemudian pada point (d) siswa diminta untuk menentukan harga $\mathrm{V}$. Pada tahap ini siswa diarahkan untuk mengkorelasikan antara persamaan laju reaksi, orde reaksi, dan harga tetapan laju (k) yang didapat untuk menentukan harga V. Pada soal nomor 5 siswa arahkan untuk mampu menguraikan persamaan laju rekasi menjadi komponenkomponen yang lebih kecil, dengan mengaplikasikan beberapa rumus pada materi laju reaksi sebagai dasar untuk menemukan fokus permasalahan. Dimana diawali dari penentuan persamaan laju reaksi, lalu penentuan orde rekasi, kemudian penentuan harga tetapan kesetimbangan yang digunakan sebagai dasar untuk menentuakan laju reaksi. Dalam setiap point pertanyaan pada soal nomor 5 memiliki hubungan atau katerkaitan. Hal ini merupakan gambaran dari level menganalisis.

Soal nomor 6 adalah soal tergolong pada jenjang ranah 
kognitif C4 (menganalisi). Rumusan soal pada nomor 6 menginginkan siswa untuk menentukan harga tetapan kesetimbangan konsentrasi (Kc). Pada soal ini siswa diberikan narasi tentang kesetimbangan kimia "Bila $1 \mathrm{~mol}$ Co dan I mol $\mathrm{H}_{2} \mathrm{O}$ direaksikan sampai terjadi kesetimbangan dan tersisa 0,2 mol CO. Tahap awal yang dilakukan siswa untuk menjawab soal ini yaitu membuat reaksi kesetimabangan berdasarkan narasi yang terdapat pada soal. Pada tahap ini siswa diarahkan untuk membuktikan kebenaran dari narasi yang terdapat pada soal bahwa memang tersisa 0,2 mol CO dalam keadaan setimbang pada reaksi kesetimbangan. Dalam arti lain siswa diarahkan untuk menemukan seba-akibat dari narasi tersebut. Misalnya, mengapa tersisa $0,2 \mathrm{~mol}$ dalam keadaan setimbang. Apa alasannya atau apa sebabnya. Melalui reaksi kesetimbngan kimia yang dibuat siswa dapat menemukan sebab-akibat dari narasi tersebut. Sehingga siswa bisa menyimpulkan kebenaran dari narasi tersebut dan siswa dapat melangkah ketahap selanjutnya. Hal itu dilakukan siswa sebagai perwujudan dari level menganalisis. Setelah didapatkan mol sisa untuk $\mathrm{CO}$, $\mathrm{CO}_{2}$ dan $\mathrm{H}_{2}$ maka siswa diarahkan untuk menghitung harga $\mathrm{Kc}$.
Untuk menghitung harga Kc siswa diarahkan untuk memahami konsep dalam membuat tetapan kesetimbangan dalam konsentrasi untuk diterapkan dalam membuat tetapan kesetimbangan dari reaksi kesetimbangan yang dibuat dengan mengimplementasikan mol sisa hasil reaksi yang diperoleh dari reaksi kesetimbangan yang dibuat.

Rumusan soal pada nomor 7 yaitu adalah soal tergolong pada jenjang ranah kognitif C4 (menganalisi). ). Pada soal ini siswa diberikan narasi tentang kesetimbangan kimia "Jika dalam keadaan setimbang terdapat 2 mol gas $\mathrm{Cl}_{2}$ dan tekanan totalnya 2,1 atm, hitunglah harga Kp nya". Tahap awal yang dilakukan siswa untuk menjawab soal ini yaitu siswa harus membuat reaksi kesetimbangan kima pada narasi yang terdapat pada soal. Pada tahap ini siswa diarahkan untuk membuktikan kebenaran dari narasi yang terdapat pada soal bahwa memang tersisa $2 \mathrm{~mol}$ CO dalam keadaan setimbang. Dengan kata lain siswa diarahkan untuk menemukan sebab akibat dari narasi tersebut. Misalnya, mengapa tersisa $2 \mathrm{~mol}$ dalam keadaan setimbang. Apa alasannya atau apa sebabnya. Melalui reaksi kesetimbnag kimia yang dibuat siswa dapat menemukan sebab akibat dari narasi tersebut Sehingga siswa 
bisa menyimpulkan bahwa jumlah mol yang didapat itu sudah benar. Setelah itu, siswa menguraikan hasil reaksi kesetimbangan tersebut menjadi komponen-komponen yang lebih kecil, dengan mengaplikasikan beberapa rumus. Seperti, rumus mol, rumus mol total dan rumus tekanan parsial gas sebagai dasar untuk menentukan harga $\mathrm{Kp}$. Hal itu dilakukan siswa sebagai perwujudan dari level menganalisis level menganalisis.

Dalam penentuan jenjang kognitif pada soal tentu saja harus disesuaikan dengan proses pembelajaran yang dilakukan. Kurikulum 2013 mengarahkan guru untuk menerapkan high order thingking (HOST) atau berpikir tingkat tinggi. Untuk dapat mencapainya, maka guru harus membiasakan siswa untuk berpikir tingkat tinggi mulai dari perencanaan pembelajaran, pelaksanaan proses pembelajaran serta soal-soal yang digunakan untuk mengevaluasinya juga harus berada pada jenjang tingkat berpikir tinggi. Pada soal UAS mata pelajaran kimia kelas XI semester ganjil di SMA Negeri 2 Tomia tahun ajaran 2019/2020 terdapat 1 butir soal dalam kategori C2(Memahami), 3 butir soal dalam kategori C3 (mengaplikasikan) dan 3 butir soal dalam kategori C4 (menganalisis). Maka, dari 7 butir soal terdapat 3 butir soal yang berada dalam kategori berpikir tinggi pada level C4 (Menganalisis) yaitu soal nomor 5, 6 dan 7 .

Dalam penyusunan soal ulangan akhir semester ganjil mata pelajaran kimia kelas XI di SMA Negeri 2 Tomia tahun ajaran 2019/2020 guru yang bersangkutan tidak membuat kisikisi soal. Kisi-kisi soal harus dibuat sebelum penyusunan soal karena kisi-kisi soal merupakan acuan dalam penyusunan soal. Hal ini hendaknya menjadi koreksi bagi guru penyusun soal tersebut.

\section{Kesimpulan}

Dari hasil yang diperoleh dalam menganalisis butir soal UAS mata pelajaran kimia kelas XI semester ganjil tahun ajaran 2019/2020 di SMAN 2 Tomia sehubungan dengan penelitian ini, dapat dikemukakan kesimpulan sebagai berikut :

1. Seluruh butir soal adalah soal yang valid. Bisa dilihat dari masing-masing soal memiliki nilai rhitumg $\geq$ nilai rtabel pada taraf kepercayaan $95 \%$ $\left(a_{0,05}\right)$.

2. Seluruh butir soal adalah soal yang reliable. Bisa dilihat dari hasil analisis reliabilitas soal memiliki derajat keterandalan yang tinggi. 


\section{DAFTAR PUSTAKA}

Depdiknas. 2009. Analisis Butir Soal. Departemen Pendidikan Nasional. Jakarta.

Khaerudin. 2015. Kualitas Instrumen Tes Hasil Belajar. Jurnal Madaniyah, Vol 2(9): 2013-2014

khaerudin77@yahoo.com. Bandung.

Nur, A. S. dan Palobo, M. 2018. Pelatihan Analisis Butir Soal Berbasis Komputerisasi Pada Guru SD. Jurnal Pengabdian Kepada Masyarakat. Vol 1(1): 5-6. Universitas Musamus Merauke. Merauke.

Peraturan Menteri Pendidikan Nasional No.41 tahun 2007 tentang Standar Proses.

Popham, W. dan James. 2002. Classroom Assessment: What Teachers Need to Know, Boston: Allyn and Bacon. Amerika.

Prabayanti, N. M. D., Sudiana, K., dan Wiratini, N. M. 2018. Analisis Tes Ulangan Kenaikan Kelas Buatan Guru Mata Pelajaran Kimia. Jurnal Pendidikan Kimia Indonesia. Vol. 2(1): 26-27. Universitas Pendidikan Ganesha. Yogyakarta.

Purwanto. 2011. Prinsip-prinsip dan Teknik Evaluasi Pembelajaran.PT Remaja Rosdakarya. Bandung.
Suaedi, A. 2016. Analisis Terhadap Kualitas Butir Soal Buatan Guru IPA Kelas VIII MTS. Negeri Slawi Tahun Pelajaran 2015/2016. Jurnal Kamil. Vol 3(9):2 MTSN Slawi. Tegal

Suryani, Y.E. 2017. Pemetaan Kualitas Empirik Soal Ujian Akhir Semester Pada Mata Pelajaran Bahasa Indonesia SMA di Kabupaten Klaten. Jurnal Penelitian dan Evaluasi Pendidikan. Vol. 21(2):143. Universitas Widya Dharma. Kalimantan Tengah.

Widodo, A. 2006. Revisi Taksonomi Bloom dan Pengembangan Butir Soal. Jakarta: Puspendik. 